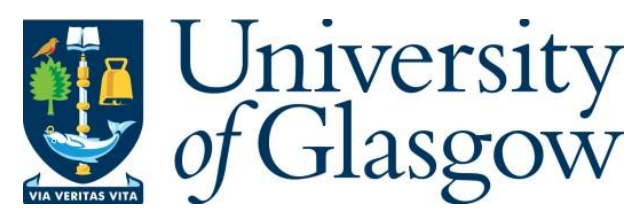

Dai, W., Dong, J., Yan, W. and Xu, J. (2017) Study on each phase characteristics of the whole coal life cycle and their ecological risk assessment - a case of coal in China. Environmental Science and Pollution Research, 24(2), pp. 1296-1305.

There may be differences between this version and the published version. You are advised to consult the publisher's version if you wish to cite from it.

http://eprints.gla.ac.uk/194001/

Deposited on: 5 September 2019

Enlighten - Research publications by members of the University of Glasgow http://eprints.gla.ac.uk 


\section{Study on each phase characteristics of the whole coal life cycle and their ecological risk assessment - a case of coal in China}

Wenting Dai ${ }^{1,2}$ \& Jihong Dong ${ }^{1,2}$ \& Wanglin $\mathrm{Yan}^{3}$ \& Jiren $\mathrm{Xu}^{4}$

Abstract: The paper divided the whole coal life cycle, ex- plained each phase characteristics, and took coal mine in China as a study case to assess the ecological risk in coal utilization phase. The main conclusions are as follows: (1) the whole coal life cycle is divided into coal mining, process- ing, transportation, utilization, and waste disposal. (2) The key points of production organization and characteristics in the five phases have great differences. The coal mining phase is characterized by the damage of the key ecological factors (water, soil, atmosphere, vegetation, etc.) damaged while the coal processing phase by discharging waste. The characteris- tics in coal transportation phase mainly performance as escap- ing and migration of atmospheric pollutants. In coal utilization phase, the main characteristics are aggravation of greenhouse effect. The main characteristics of waste disposal phase are accumulation of negative ecological effects on the land. (3) The ecological risk of soil heavy metals is serious in coal utilization phase. The potential ecological hazard coefficients of $\mathrm{Pb}$ and $\mathrm{As}$ in coal, residue and ash are all lower than 40, presenting low environmental impact on soil; the potential ecological risk coefficients of $\mathrm{Cd}$ are higher than 60, nearly half of their potential ecological risk coefficients are higher than 160, which presents high environmental pollution impact on soil; Hg's potential ecological risk coefficients are higher than 320, presenting the highest environmental pollution im- pact on soil; the comprehensive pollution indexes in coal, residue, and ash are relatively high, which means the pollution hazard potential to soil environment is high. (4) The ecologi- cal risk of the atmospheric solid suspended matter is relatively strong in coal utilization phase. The ecological risk of $\mathrm{Cd}$ and As in primary flue gas is both lower than net flue gas. The geoaccumulation indexes of $\mathrm{Cd}$ and $\mathrm{Hg}$ in primary flue gas and net flue gas are both higher than 5, presenting the very strong ecological risk; $50 \%$ of the geoaccumulation index values of As are between 3 and 4, which has also presenting a strong ecological risk while $\mathrm{Pb}$ does not present the ecolog- ical risk characterization.

Keywords: Coal life cycle, Phase division, Phase characteristics, Ecological risk assessment, Xuzhou mining

\section{Introduction}

Life cycle is the sequence of life stages that an organism un- dergoes from birth to reproduction 
ending with the generation of the off spring (Ma et al. 2010; Zhu 2004). Life cycle as- sessment (LCA) is an evaluation of a product, process or ac- tivity from the collection and processing of raw materials to production, transportation, sale, utilization, recovery, conser- vation, recycling, and final disposal process throughout the whole life cycle of the relevant environmental load (Consoil et al. 1993; Fan et al. 2007; ISO/DIS 1997). The basic structure of LCA includes objective definition and scope de- termination, inventory analysis, impact assessment, and im- provement analysis. Recently, LCA has been widely used in the fields of energy utilization and environmental impact as- sessment of the product or service system (Finnveden et al. 2009; Distsele and Awuah 2012; Liang et al. 2013), and most of them are directly or indirectly related to the coal resources.

The exploitation and utilization of coal resources have obvious life cycle (Wang 2007; AwuahOffei and Adekpedjou 2011, Burchart-Korol et al. 2016), and the whole coal life cycle refers to the various phases and whole process from the raw coal mining to the final waste disposal. For a long time, coal resources have played an important role in providing energy for human use due to the characteristics of cheapness and reliability. However, the processes of coal exploitation and utilization are al- ways along with the phenomenon of disturbing and dam- aging to the ecological environment elements in regional ecosystem seriously, e.g., the concentration of atmospheric PM2.5 increasing, PM is the abbreviation of particulate matter and PM2.5 means the particulate matter less than or equal to $2.5 \mu \mathrm{m}$ in the atmosphere, (Zheng 2014; Liberda et al. 2015), water pollution (Bukowski 2015), land destruction ( $\mathrm{Li}$ 2009). Therefore, the research of eco- logical destruction and restoration in the processes of coal exploitation and utilization have become an important field, and most of the researches are focusing on three aspects: major environmental pollution problems in the processes of coal exploitation and utilization (Mangena and Brent 2006; Chinh et al. 2007), comprehensive utilization of mine water, coal gangue and other wastes produced along with the coal production (Mukherjee et al. 2008; Wang et al. 2012), and technology and measures of clean coal (Solveig 2005; Wang 2011; Alvaro et al. 2015. The priority for production organization, the level, and form pollution as well as the environmental behavior characteristics and ecological risk on environment in each phase of the coal life cycle are different, and it is necessary to analyze each phase characteristics and evaluate the ecological risk based on the rational phase division of the whole coal life cycle. The research of applying life cycle theory to the coal exploitation and utilization is incomplete for now, which mainly applies the LCA theory to assess the ecological impact on the processes of coal exploitation and utilization (Qian et al. 2003; Naser and Timothy 2008; Xiang et al. 2015), and lack of scientific, systematic research on the ecological risk assessment in each phase of the whole coal life cycle. Therefore, the paper studied the phase division of the whole coal life cycle and each phase characteristics, and took coal in Xuzhou, China as an example to evaluate the ecological risk in coal utilization phase. Results of the study can 
clear each phase characteristics of the whole coal life cycle and the ecological risk of coal exploitation and utilization, and so that provide proposals for rational exploitation of coal resources.

\section{Phase division of the whole coal life cycle}

\section{Division basis}

Life cycle theory has been developed and improved continuously, and gradually penetrated into various industries in the human economic society, the coal industry is no exception. In April 2000, nine top mineral companies in the world started the Mining, Minerals and Sustainability (MMSD) project and started to introduce the life cycle theory into the study on sustainable development of mining industry. In 2002, the Implementation Plan of the World Summit on Sustainable Development summited in World Summit on Sustainability Development Conference, Johannesburg, South Africa, proposed that all relevant agencies need to consider the whole mining life cycle, and governments are advocated to use the life cycle theory to evaluate the contribution of mineral re-sources and mining industry to sustainable development.

The coal mine life cycle refers to the whole process from construction to the mine closure, and its research object is coal mine. For now, there are many references have been researched the phase division of the coal mine life cycle, e.g., Tong divided the coal mine life cycle into coal mine construction phase, mine production phase, expansion phase, and abandoned treatment phase (Tong et al. 2013); Wang divided the coal mine life cycle into planning period, building well period, putting into operation period, production period, stable production period, aging period, and succeeding period (Wang et al. 2009); Donoghue divided the coal mine life cycle into mine construction stage, production stage, recession stage, and transition stage (Donoghue 2000).

There are also many researches on the phase division of the coal life cycle. Steinmann divided the coal life cycle into extraction stage, transportation stage, and a power plant (Steinmann et al. 2014); Babbitt divided the coal life cycle into coal mining and preparation, coal combustion, and coal combustion product disposal (Babbitt and Lindner 2008). Some major coal producing and consuming countries also have their own phase division of the coal life cycle. For example, the USA is one of the largest coal producing and consuming countries in the world, which has established an integrated, efficient clean coal production and energy conversion system. The system mainly includes coal mining, coal drying, and power plant combustion to produce electric energy and water vapor. South Africa is the third largest coal exporter in the world, secondly only to Australia and the USA. In South Africa, about $40 \%$ of fuel comes from coal re- sources, and the coal resources are mainly used for combustion power generation and oil refining. The process of coal exploitation and utilization includes coal mining, coal washing and liquefaction, and coal utilization. Poland is rich in coal resources and is 
the most important coal producing and exporting countries in the world. Its coal mining history has been more than 400 years, $65 \%$ of coal resources in Poland are used for power generation and centralized power supply, and the process of coal exploitation and utilization includes coal mining, coal screening and machining of raw coal, coal combustion for power generation and energy supply.

\section{Five phases division for the whole coal life cycle}

By summarizing the existing research results and the processes of coal exploitation and utilization in major coal producing countries of the world, the coal exploitation and utilization both contain coal mining, coal processing, and coalutilization. In China, coal resources are mainly distributed in the northwest region, while the coal consumption industries are concentrated in the southeast coastal areas. Due to the situation that the coal resources distribution is not adapted to the productive forces, the long distance coal transportation patterns from west to east and north to south are difficult to change in the short term. At the same time, $90 \%$ of coal mine in China is underground mining, leading the surface subsidence becomes one of the main land destruction forms, and waste backfill treatment is one of the main restoration technologies. Therefore, the coal transportation and waste disposal are also important parts in the process of coal exploitation and utilization in China. By combining with the processes of coal exploitation and utilization in the main coal mining countries of the world, relevant researches, and the characteristics of coal and coal mine in China, the whole coal life cycle can be divided into five phases: coal mining, coal processing, coal transportation, coal utilization, and waste disposal (Fig. 1). The phase division of the whole coal life cycle can reflect the integrity of the coal life cycle and the diversity among each phase characteristics, and conducive to systematically study on the coal ecological risk assessment.

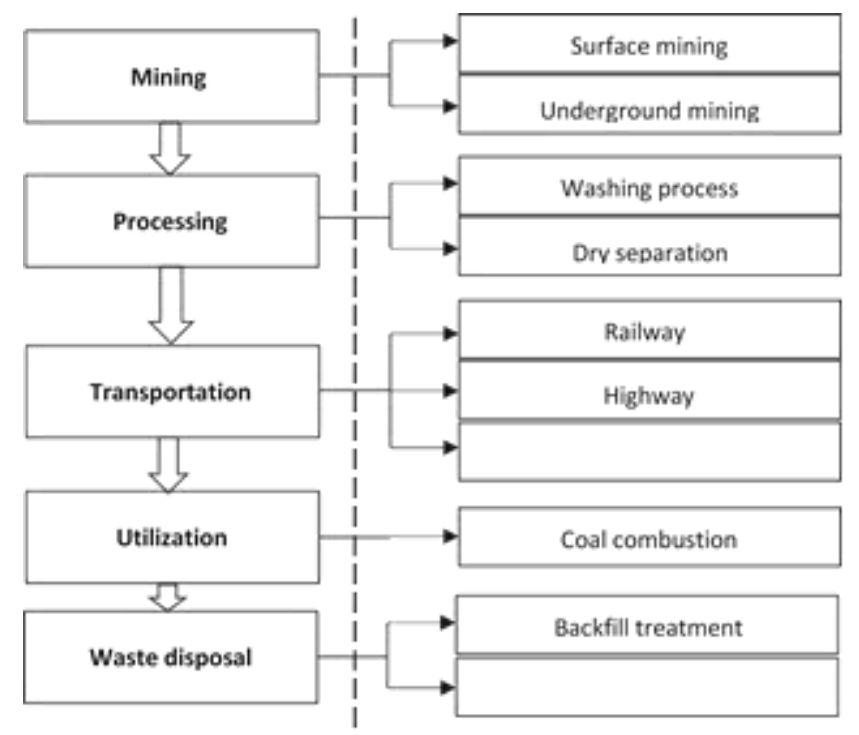

Fig. 1 Phase division of the whole coal life cycle 


\section{Each phase characteristics of the whole coal life cycle}

\section{Description in the whole process of the coal life cycle}

The whole processes of coal exploitation and utilization are divided into four periods, planning period, commissioning period, stable exploitation period, and recession period. The five phases of the whole coal life cycle are a continuous cycle process, and the priority for each period of the coal exploitation and utilization is different. Coal resources are the major basic energy for the development of the national economy, which results in the continuous accumulation of ecological negative effects, imbalance of the ecosystem, and threating the ecological stability, and security of coal mining area. In addition, the high strength exploitation accelerates the depletion of coal resources and result in a series of social, ecological, economic problems (e.g., forming the single industrial structure, seriously damaging the ecosystem, and in- creasing unemployment and poverty in a certain degree), which restricts the sustainable development of the society and ecology in the mining area, even the whole region. The whole process characteristics of coallife cycle are shown in Fig. 2.

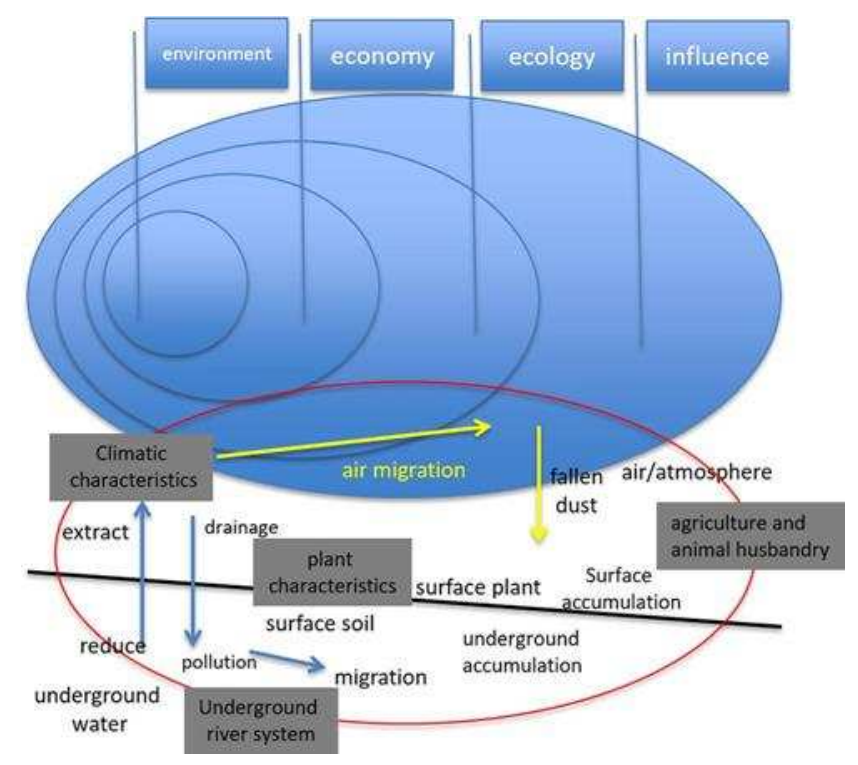

Fig. 2 Characteristics in the whole process of coal life cycle

\section{Main characteristics in each phase}

\section{Coal mining phase: water, soil, atmosphere, and other key ecological elements are damaged}

Due to the non-mobility of coal resources, the infrastructure construction and coal mining must lead to the destruction of water, soil, atmosphere, and other key ecological elements in mining area. The negative effects result in a) water resources depletion. Mining activities change the 
hydrogeological conditions in the mining area, the structures of coal seam surrounding rock and aquifer are destroyed, which results in the underground water and surface water in coal mining swarming into the pit. Therefore, the surface water system is damaged, the underground water level is reduced, and the water resource is exhausted. At the same time, a large number of untreated mine water is discharged directly, which makes the rivers and lakes surrounding the mining area polluted seriously. b) Land resource damage. The main damage forms of land resources caused by coal mining are land pressure, land digging, and land collapse. Coal gangue and other solid waste pressure a large number of land resources, and the coal gangue emission is generally accounted for $20 \%$ of the raw coal's output. In China, over $90 \%$ of coal mining is underground mining, and land col- lapse is the main form of land destruction, which results in a sharp reduction of arable land area, and exacerbates the contradiction between land and people. It is also easy to cause geological disasters. C) Atmosphere pollution. The coal dust from open pit blasting and dump gangue, waste gas, and coal mine gas are the main atmosphere pollution sources in the coal mining phase. According to the statistics of the national economic and social development during 2005 to 2013 , in 2013, one ton of raw coal produced with $5.27 \mathrm{~m}^{3}$ gas emission, and the total amount of gas emitted from coal mining in China was about 19.763 billion $\mathrm{m}^{3}$, which increased the regional greenhouse effect. d) Biodiversity reduction. Ground deformation and collapse caused by coal mining destroy the soil ecosystem stability, and make soil microbial species and soil quality decrease. It has direct impact on the transport and transformation of material and nutrient in plant ecosystem, and the surface vegetation reduces. In this phase, the ecological problems are various and have wide distribution and great harm, and the primary ecosystem is disturbed; however, the demand for labor resources is large in this phase, which can promote the region- al employment and economic development.

\section{Coal processing phase: solid and liquid waste are discharged}

Coal processing refers to process the raw coal to improve its quality or use value by mechanical, physical, chemical, and other methods. It mainly includes crushing and screening, washing or dry cleaning, coal blending, and indigenous coking. Coal processing process produces a large number of toxic and harmful pollutants, the effects include: a) Gangue, coal slime, and other solid waste produced in washing and dry cleaning process pile up directly, which presses the land and pollutes the soil and groundwater in mining area seriously due to the long-term weathering and eluviation. b) Wastewater containing SS (solid suspended matter), COD (chemical oxygen demand), BOD5 (biochemical oxygen demand), and other toxic and harmful substances are discharged directly before treatment, leading to the serious pollution of the surrounding water bodies, and endangering the surrounding animal and human health. c) Raise dust and coal dust produced in coal crushing and screening, transport 
process, lead to the inhalable particulate matter content in the atmosphere increasing. The atmospheric environment quality decreases obviously, and the workers' health is threatened. In this phase, the main problem is the solid and liquid waste are discharged directly, which damages the water and soil ecosystem; however, the quality and use efficiency of raw coal are improved, and the economic development of the coal enterprises and region are promoted in this phase.

\section{Coal transportation phase: atmospheric pollutants escape}

The coal production base is away from the consumer base in China, which makes the coal transportation become an integral part of the whole coal life cycle. Years of development, China has formed coal transportation pattern of coexistence with various transport modes (i.e., railway, highway, shipping, and waterway). The railway is the main means, waterway and highway are the important supplement, and highway is mainly for short distance transport (Wang 2013). Coal transportation contains a series process of the coal storage, loading and transportation, and the dust, coal dust and traffic exhaust produced in the process pollute the atmospheric environment. According to statistics, due to the railway and highway of coal transportation, there is at least 10 million tons of the coal dust discharging to the atmosphere every year. At the same time, because of the coal spontaneous combustion during the transportation process, there are up to 20-30 tons of sulfur oxides, sulfur hydride, and other toxic gas discharging to the atmosphere every year (Wang 2013). In the phase, the atmospheric pollutants and traffic noise interfere the humanity along the traffic line and have a negative impact on the agriculture, fisheries, and animal husbandry on both sides of the transportation routes; however, the source and consumption areas of coal resources are linked, the exchanges and joint development of regional economy are promoted, and the conditions in insufficient effective demand of local economic development are made up in this phase (Dai 2013).

\section{Coal utilization phase: greenhouse gas effect aggravates}

Coal resources are mainly used to direct combustion, and it is divided into power plant coal, industrial coal, and civil burning coal. By the end of 2013, the total installed capacity of China was 1.246 billion kilowatts, and there was 0.785 billion kilowatts thermal power produced by coal combustion, which accounts for $63 \%$ of the total generating capacity (Wu 2014). A large number of toxic and harmful elements are discharged in the process of power plant combustion, a) carbon dioxide $\left(\mathrm{CO}_{2}\right)$, sulfur dioxide $\left(\mathrm{SO}_{\mathrm{X}}\right)$, nitrogen oxides $\left(\mathrm{NO}_{\mathrm{X}}\right)$, particulate matter, and other harmful gases are discharged to the atmosphere in the process of coal combustion, which aggravates the regional greenhouse gas effect, makes the atmospheric environment polluted seriously, and threatens the workers' and surrounding residents' health. According to the relevant department statistics, $70 \%$ of the total suspended particulate matter, $90 \%$ of $\mathrm{SO}_{2}, 67 \%$ of $\mathrm{NO}_{\mathrm{x}}, 85 \%$ of $\mathrm{CO}_{2}$ are derived from the coal utilization (Wang 2011). b) 
The waste water is discharged to the environment directly, which causes serious pollution of surface water and underground water. In addition, it harms the surrounding crops, animals, and human health through irrigation, drinking, exposure, and other ways. c) The slag and fly ash generated in the process of coal combustion stack on the land directly, which presses and pollutes the land. The long-term weathering and leaching on the solid waste would cause serious pollution of the surrounding atmosphere, soil and underground water. In this phase, it mainly destructs and pollutes the atmosphere ecosystem; however, the coal resources are transformed into heat energy, which pro- vides basic protection for the national economy development, and play a decisive role in the national economic development.

\section{Waste disposal phase: negative influence on land ecology}

The waste generated in the processes of coal exploitation and utilization mainly includes coal mining tailings and thermal power plant waste, such as coal gangue and fly ash. The waste disposal phase mainly includes the waste recycling and land- fill treatment. At present, the waste recycling mainly refers to acting as the filling materials, and producing building materials. Because of coal gangue, fly ash, and other waste materials containing heavy metals and other toxic and harmful elements, acting as filling materials may pollute the soil, groundwater, and planting crops, for example, heavy metal pollution of the reclamation soil in mining area (Dong et al. 2010). In this phase, a large number of mining waste residue is treated, the ecological problems are improved, but the negative effects of the soil ecosystem are accumulated; however, the land subsidence in mining area is controlled and treated, the area of pressure and damaged land is decreased, and the cost of the ecological treatment in mining area is reduced.

The main characteristics, environmental behavior, ecological response, ecosystem change, social/economic systemimpact, and response plan/measure in the five phases of the whole coal life cycle are different, and they are shown in Table 1 specifically.

Table 1 Characteristics in each phase of the whole coal life cycle

\begin{tabular}{|c|c|c|c|c|c|c|}
\hline Phase & $\begin{array}{c}\text { Main } \\
\text { characteristics }\end{array}$ & $\begin{array}{c}\text { Environmental } \\
\text { behavior }\end{array}$ & $\begin{array}{l}\text { Ecological } \\
\text { response }\end{array}$ & $\begin{array}{l}\text { Ecosystem } \\
\text { change }\end{array}$ & $\begin{array}{l}\text { Social/economic } \\
\text { system impact }\end{array}$ & $\begin{array}{c}\text { Response } \\
\text { plan/measure }\end{array}$ \\
\hline $\begin{array}{c}\text { Coal } \\
\text { mining }\end{array}$ & $\begin{array}{l}\text { Water, soil, } \\
\text { atmosphere } \\
\text { and other key } \\
\text { ecological } \\
\text { elements are } \\
\text { damaged }\end{array}$ & $\begin{array}{c}\text { Destruction of the } \\
\text { surrounding rock and } \\
\text { aquifer structure, } \\
\text { waste water and gas } \\
\text { emissions, pressure } \\
\text { and digging land, etc. }\end{array}$ & $\begin{array}{l}\text { Water resources } \\
\text { depletion, land } \\
\text { resource damage, } \\
\text { air pollution, } \\
\text { biodiversity } \\
\text { reduction }\end{array}$ & $\begin{array}{c}\text { Primary } \\
\text { ecosystem } \\
\text { disturbance }\end{array}$ & $\begin{array}{c}\text { Regional } \\
\text { economic } \\
\text { development, } \\
\text { mining area } \\
\text { stability }\end{array}$ & $\begin{array}{c}\text { Reclamation } \\
\text { project }\end{array}$ \\
\hline $\begin{array}{c}\text { Coal } \\
\text { processing }\end{array}$ & $\begin{array}{c}\text { Solid and } \\
\text { liquid waste } \\
\text { are discharged }\end{array}$ & $\begin{array}{c}\text { Solid waste, } \\
\text { wastewater containing } \\
\text { toxic and harmful } \\
\text { elements are } \\
\text { discharged, dust is }\end{array}$ & $\begin{array}{l}\text { Air particulate } \\
\text { matter increased, } \\
\text { water and soil } \\
\text { pollution, human } \\
\text { health is harmed. }\end{array}$ & $\begin{array}{l}\text { Water and } \\
\text { soil } \\
\text { ecosystem } \\
\text { are damaged }\end{array}$ & $\begin{array}{l}\text { Use efficiency } \\
\text { is improved, } \\
\text { enterprise } \\
\text { economy is } \\
\text { developed. }\end{array}$ & $\begin{array}{c}\text { Cleaner } \\
\text { production }\end{array}$ \\
\hline
\end{tabular}




\begin{tabular}{|c|c|c|c|c|c|c|}
\hline \multicolumn{7}{|c|}{ generated, etc. } \\
\hline $\begin{array}{c}\text { Coal } \\
\text { transportation }\end{array}$ & $\begin{array}{l}\text { Atmospheric } \\
\text { pollutants } \\
\text { escape }\end{array}$ & $\begin{array}{c}\text { Dust, coal dust, } \\
\text { vehicle exhaust and } \\
\text { other air pollutants } \\
\text { escape }\end{array}$ & $\begin{array}{c}\text { Air pollution } \\
\text { along the traffic } \\
\text { route, agriculture, } \\
\text { fishery and animal } \\
\text { husbandry are } \\
\text { damaged. }\end{array}$ & $\begin{array}{l}\text { Human } \\
\text { ecosystem } \\
\text { violation }\end{array}$ & $\begin{array}{c}\text { Regional } \\
\text { economic } \\
\text { exchanges and } \\
\text { common } \\
\text { development are } \\
\text { promoted. }\end{array}$ & $\begin{array}{c}\text { Zero } \\
\text { discharge }\end{array}$ \\
\hline $\begin{array}{c}\text { Coal } \\
\text { utilization }\end{array}$ & $\begin{array}{l}\text { Greenhouse } \\
\text { gas effect } \\
\text { aggravates }\end{array}$ & $\begin{array}{l}\text { Waste gas and water, } \\
\text { slag, fly ash and other } \\
\text { solid waste residue } \\
\text { are discharged } \\
\text { directly }\end{array}$ & $\begin{array}{c}\text { Air quality } \\
\text { declines, surface } \\
\text { water is polluted, } \\
\text { land is pressed. }\end{array}$ & $\begin{array}{l}\text { Atmosphere } \\
\text { ecosystem } \\
\text { destruction }\end{array}$ & $\begin{array}{l}\text { Basic energy for } \\
\text { the national } \\
\text { economy } \\
\text { development is } \\
\text { provided. }\end{array}$ & $\begin{array}{c}\text { Green } \\
\text { technology }\end{array}$ \\
\hline $\begin{array}{c}\text { Waste } \\
\text { disposal }\end{array}$ & $\begin{array}{c}\text { Negative } \\
\text { influence on } \\
\text { land ecology }\end{array}$ & $\begin{array}{l}\text { Solid waste is stacked } \\
\text { directly, and the land } \\
\text { is filled with } \\
\text { hazardous waste. }\end{array}$ & $\begin{array}{l}\text { The harmful } \\
\text { elements in filling } \\
\text { materials pollute } \\
\text { soil, underground } \\
\text { water, and plants. }\end{array}$ & $\begin{array}{l}\text { Negative } \\
\text { effects on } \\
\text { land } \\
\text { ecosystem } \\
\text { are } \\
\text { accumulated }\end{array}$ & $\begin{array}{l}\text { The cost of } \\
\text { ecological } \\
\text { management in } \\
\text { mining area is } \\
\text { reduced. }\end{array}$ & $\begin{array}{l}\text { Ecological } \\
\text { restoration }\end{array}$ \\
\hline
\end{tabular}

\section{Characteristic inventory}

Life cycle inventory is an important basis for the ecological impact evaluation and improvement proposal in life cycle assessment. It is a process of compiling and quantitatively evaluating the input and output of the whole life cycle in a given product system, and its functions are as follows: a) comprehensive understanding the interrelated product systems; b) identifying research objectives and scope, defining the analysis system, and establishing the system model; c) quantitative analyzing the input and output of energy and materials in the product system, and establishing the basic line of system environmental behavior; d)identifying the proportion of energy and raw material consumption, pollutant emission in the pro- duce system, and determining process and environmental improvement measures;e) providing scientific data to determine the ecological standard, and establishing the sharing mechanism of environmental cost (Peng 2012). LCI is a progressive process and mainly includes preliminary inventory, target inventory, result inventory, and standard inventory.

Preliminary inventory of the whole coal life cycle is de- fined as the preparation work before collecting the input and output data in each phase of the whole coal life cycle, which includes determination of the objectives and scope, and making the input-output environmental information table of the whole coal life cycle. Target inventory analysis refers to making clear the input and output items in each phase of the whole coal life cycle, and the way to obtain the inventory data, including data collection and validation. Result inventory is collecting and processing the target inventory data of the whole coal life cycle, including correlation of data and unit process, correlation of data and functional unit, and data merging. Standard inventory is a sensitivity analysis on the results of the whole coal life cycle, determining the importance of data in each phase, and amending the system boundary of the whole coal life cycle defined initially. Taking Jiangzhuang coal mine of Huanghuaihai plain, China as example, the inventory data in each phase of the whole coal life cycle are shown in Table 2. 
Table 2 Characteristics inventory of various stages of coal's life cycle

\begin{tabular}{|c|c|c|c|c|}
\hline \multicolumn{3}{|c|}{ Phase } & Input data & Output data \\
\hline \multicolumn{3}{|c|}{$\begin{array}{l}\text { Infrastructure } \\
\text { construction }\end{array}$} & $\begin{array}{l}\text { Square, wood, steel products, } \\
\text { cement, water resources, and } \\
\text { power consumption }\end{array}$ & Waste water, waste gas, dust, noise, etc. \\
\hline $\begin{array}{l}\text { Coal } \\
\text { mining }\end{array}$ & \multicolumn{2}{|c|}{ Raw coal mining } & $\begin{array}{l}\text { Fuel, water resources, } \\
\text { equipment power } \\
\text { consumption (such as } \\
\text { continuous mining machine, } \\
\text { filling machine, etc.), } \\
\text { occupation of land }\end{array}$ & $\begin{array}{l}\text { Coal production, solid waste (coal } \\
\text { gangue, etc.), mine water, gas, land use } \\
\text { change. Main pollution factors : } \mathrm{CO}_{2} \text {, } \\
\text { CO, NOx, } \mathrm{CH}_{4} \ldots . . .\end{array}$ \\
\hline \multicolumn{3}{|c|}{ Coal processing } & $\begin{array}{c}\text { Fuel, power loss of } \\
\text { equipment (Such as } \\
\text { screening machine, crusher, } \\
\text { heavy medium separator, } \\
\text { etc.), shipping tool fuel } \\
\text { consumption, water } \\
\text { resources }\end{array}$ & $\begin{array}{l}\text { Wastewater, waste gas, solid waste } \\
\text { (such as coal, solid impurities in raw } \\
\text { coal etc.). Main pollution factors: } \mathrm{CO}_{2} \text {, } \\
\mathrm{CO}, \mathrm{NOx}, \mathrm{CH}_{4}, \mathrm{~S}, \mathrm{~Pb}, \mathrm{Cd}, \mathrm{Hg}, \mathrm{As} . . . .\end{array}$ \\
\hline \multicolumn{3}{|c|}{ Coal transportation } & Fuel, water, etc. & $\begin{array}{l}\text { Dust, tail gas, noise, etc. Main pollution } \\
\text { factors: } \mathrm{CO}, \mathrm{NO}_{\mathrm{x}}, \mathrm{Pb}, \mathrm{Cd}, \mathrm{Hg}, \mathrm{As} . . . . .\end{array}$ \\
\hline \multicolumn{3}{|c|}{ Coal utilization } & $\begin{array}{l}\text { Coal, water resources, power } \\
\text { loss of equipment, etc. }\end{array}$ & $\begin{array}{l}\text { Power generation, waste water, waste } \\
\text { gas, solid waste (coal cinder, coal ash, } \\
\text { etc.). Main pollution factors: } \mathrm{CO}_{2}, \mathrm{CO} \text {, } \\
\mathrm{SO}_{x}, \mathrm{NO}_{x}, \mathrm{~Pb}, \mathrm{Cd}, \mathrm{Hg}, \mathrm{As} . . . .\end{array}$ \\
\hline \multirow{2}{*}{\multicolumn{2}{|c|}{ Waste disposal }} & Recycling & $\begin{array}{l}\text { Power consumption of } \\
\text { equipment, fuel, etc. }\end{array}$ & $\begin{array}{l}\text { Recycling the waste to converse } \\
\text { available material. Main pollution } \\
\text { factors: } \mathrm{CO}_{2}, \mathrm{CO}, \mathrm{NO}_{\mathrm{x}} \ldots\end{array}$ \\
\hline & & $\begin{array}{l}\text { Backfill } \\
\text { treatment }\end{array}$ & $\begin{array}{l}\text { Square, transportation tools, } \\
\text { fuel, etc. }\end{array}$ & $\begin{array}{l}\text { Waste gas, waste water (such as } \\
\text { filtrate), landfill, land pollution. Main } \\
\text { pollution factors: } \mathrm{CO}_{2}, \mathrm{CO}, \mathrm{NO}_{\mathrm{x}} \ldots . .\end{array}$ \\
\hline
\end{tabular}

The whole coal life cycle is a very complex process, and it is difficult to assess ecological risk of all the phases clearly in a paper. In addition, previous studies have compared the eco- logical potential risk of the core phases, coal mining, transpor- tation, and utilization phase, the results show that the environmental impact of coal utilization is the highest, and the phase has the greatest ecological risk (Wang et al. 2006). Thus, the paper selected the coal utilization phase to assess the ecolog-ical risk on the environment. Xuzhou of Huanghuaihai plain is in the northwest of Jiangsu Province, China, with east longitude $116^{\circ}$ $22^{\prime} \sim 118^{\circ} 40^{\prime}$ and north latitude $33^{\circ} 43^{\prime} \sim 34^{\circ} 58^{\prime}$, which belongs to the warm temperate semi-humid monsoon climate, and has four distinct seasons, adequate light, and moderate rainfall. Xuzhou is rich in coal resources and has a long history of coal mining, it is an important coal producing area and power base in China. Therefore, the paper takes coal in Xuzhou, China as an example to assess the ecological risk of soil and atmospheric environment in coal utilization phase. 


\section{Soil ecological risk assessment in coal utilization phase}

\section{Data sources}

The data from the three power enterprises which have similar amount of scale and annual coal consumption in Xuzhou, China, is monitored and obtained by the Product Quality Inspection Center of Xuzhou, China in October 2014. The specific data is shown in Table 3.

Table 3 Discharge inventory of soil heavy metals in coal utilization phase (ug/g)

\begin{tabular}{cccccc}
\hline Company & Sample & $\mathrm{Cd}$ & $\mathrm{Pb}$ & $\mathrm{As}$ & $\mathrm{Hg}$ \\
\hline \multirow{2}{*}{ Sample } & Coal & 1.10 & 19.00 & 4.00 & 0.12 \\
source 1 & Residue & 2.90 & 31.00 & 2.00 & 0.00 \\
& Ash & 2.60 & 46.00 & 5.00 & 0.20 \\
\hline \multirow{2}{*}{ Sample } & Coal & 0.80 & 24.00 & 3.00 & 0.39 \\
source 2 & Residue & 1.30 & 18.00 & 0.20 & 0.00 \\
& Ash & 1.40 & 42.00 & 5.00 & 0.15 \\
\hline \multirow{2}{*}{ Sample } & Coal & 0.60 & 24.00 & 4.00 & 0.13 \\
source 3 & Residue & 2.40 & 20.00 & 2.00 & 0.00 \\
& Ash & 1.80 & 171.00 & 1.00 & 0.15 \\
\hline Reference values of heavy metals & 0.29 & 16.3 & 11.2 & 0.01 \\
\hline
\end{tabular}

Note: the "coal" in the table refers to the incomplete combustion of coal.

\section{Evaluation method: potential ecological risk index method}

Potential ecological risk index method, established in 1980 by Hakanson, is a method applying sedimentology theory to evaluate heavy metal's pollution and ecological damage. The method not only considers the content of heavy metal, but also links the ecological effect, environmental effect, and toxicology together. Potential ecological risk index method is based on the ratio of heavy metals and their corresponding back- ground values to establish the heavy metal ecological toxicity coefficient model. The results reflect the environment impact of a single heavy metal pollutant on a particular environment, or the comprehensive environment impact of a variety of heavy metals on a particular environment, and quantitatively classify the potential ecological risk degree of heavy metal elements. Its formula is as follows:

$$
\begin{aligned}
C_{f}^{i} & =C^{i} / C_{i} \\
E_{r}^{i} & =T_{r}^{i} C_{f}^{i} \\
R I & =\sum E_{r}^{i}
\end{aligned}
$$

where: $C_{f}^{i}$ represents the pollution coefficient of heavy metal i in a certain environment; $C^{i}$ is measured content of heavy metal i; $C_{i}$ is reference value of heavy metal i. The solid waste coal, slag and ash from coal-fired power generation enterprises are mainly discharged into the soil environment, therefore, the background values of soil heavy metals in Xuzhou city are used as the reference value (Table 3) (Lei et al. 2014); $T_{r}^{i}$ represents the toxic 
response factor, the toxicity response coefficients of $\mathrm{Cd}, \mathrm{Pb}$, As and $\mathrm{Hg}$ are 30, 5, 10 and 40 respectively (Zhuang and Jiang 2009); $E_{r}^{i}$ represents potential ecological risk factor, it is low pollution when $E_{r}^{i}$ is less than 40 , moderate pollution when $E_{r}^{i}$ is $40 \sim 80$, higher pollution when $E_{r}^{i}$ is $80 \sim 160$, high pollution when $E_{r}^{i}$ is 160 320, and very high pollution when $E_{r}^{i}$ is more than 320 (Zhuang and Jiang 2009; Wang and Qin 2007); RI represents integrated potential ecological risk index, it is low pollution when $R I$ is less than 150 , medium pollution when $R I$ is $150 \sim 300$, higher pollution when $R I$ is $300 \sim 600$, and high pollution when $R I$ is more than 600 (Peng 2012).

\section{Soil ecological risk results}

According to the formulas $11-(3)$, the potential ecological risk coefficients of soil heavy metals in coal utilization phase in Xuzhou are calculated, and the results are as shown in Table 4.

Table 4 Potential ecological risk coefficient of soil heavy metals

\begin{tabular}{ccccccc}
\hline Company & Sample & Cd & Pb & As & Hg & RI \\
\hline \multirow{2}{*}{ Sample } & Coal & 113.79 & 5.83 & 3.57 & 480.00 & 603.19 \\
source 1 & Residue & 300.00 & 9.51 & 1.79 & - & 311.30 \\
& Ash & 268.97 & 14.11 & 4.46 & 800.00 & 1087.54 \\
\hline \multirow{2}{*}{ Sample } & Coal & 82.76 & 7.36 & 2.68 & 1560.00 & 1652.80 \\
source 2 & Residue & 134.48 & 5.52 & 0.18 & - & 140.18 \\
& Ash & 144.83 & 12.88 & 4.46 & 600.00 & 762.17 \\
Sample & Coal & 62.07 & 7.36 & 3.57 & 520.00 & 593.00 \\
source 3 & Residue & 248.28 & 6.13 & 1.79 & - & 256.20 \\
& Ash & 186.21 & 52.45 & 0.89 & 600.00 & 839.44 \\
\hline
\end{tabular}

The potential ecological risk coefficients of the four kinds of heavy metals in coal, residue and ash are followed by $\mathrm{Hg}>\mathrm{Cd}>\mathrm{Pb}>\mathrm{As}$. The potential ecological risk coefficients of $\mathrm{Pb}$ and $\mathrm{As}$ in coal, residue and ash are all lower than 40 (except for some abnormal data), and their environmental impact on soil present low pollution; The potential ecological risk coefficients of $\mathrm{Cd}$ are 62.07 300, and $44 \%$ potential hazard coefficients of which are more than 160. The potential pollution impact on soil environment is high; All the potential ecological risk coefficients of $\mathrm{Hg}$ are higher than 320, and the potential pollution impact on soil environment is very high.

All the comprehensive pollution indexes of coal and ash are higher than 600, presenting the very high potential pollution impact on soil environment; while the comprehensive pollution indexes of residue are between 150 to 300 , presenting the medium potential pollution impact on soil environment.

\section{Atmosphere ecological risk assessment in coal utilization phase}

\section{Data sources}

The data from the three power enterprises which have similar amount of scale and annual coal consumption in Xuzhou, China, is monitored and obtained by the Product Quality Inspection Center 
of Xuzhou, China in October 2014. The specific data is shown in Table 5.

Table 5 Discharge inventory of atmosphere heavy metals in coal utilization phase (ug/g).

\begin{tabular}{cccccc}
\hline Company & Sample & $\mathrm{Cd}$ & $\mathrm{Pb}$ & $\mathrm{As}$ & $\mathrm{Hg}$ \\
\hline Sample & Primary flue gas & 101.37 & 2.94 & 47.81 & 5.25 \\
source 1 & Net flue gas & 909.32 & 5.04 & 55.92 & 4.14 \\
\hline Sample & Primary flue gas & 112.45 & 2.46 & 43.45 & 4.57 \\
source 2 & Net flue gas & 274.26 & 2.12 & 174.21 & 4.83 \\
\hline Sample & Primary flue gas & 50.31 & 1.34 & 356.33 & 1.87 \\
source 3 & Net flue gas & 111.51 & 1.75 & 415.89 & 1.21 \\
\hline
\end{tabular}

\section{Evaluation method: Geoaccumulation index method}

The atmospheric samples of the paper are primary flue gas and net flue gas, the solid suspended matter contents of them are high, and their deposition are strong. Therefore, geoaccumulation index method is chose to assess the ecological risk of the atmosphere. Geoaccumulation index ( $\mathrm{I}_{\text {geo }}$ ) is a kind quantitative indicator of the heavy metal pollution degree in the atmosphere, soil, and sediment. The method considers not only the effects of the anthropogenic pollution and environmental geochemistry on the background values, but also the influence of the background values caused by the natural digenesis. The calculation formula is as follows (Zhao et al. 2015; Loska 2004; Hu et al. 2013):

$$
I_{g e o}=\log _{2} \frac{C_{i}}{1.5 \times B_{i}}
$$

where: $C_{i}$ represents the measured concentration of element $\mathrm{i}$ in the sample; $B_{i}$ represents the average content of element $\mathrm{i}$ in the global shale layer, the average content of $\mathrm{Cd}, \mathrm{Pb}, \mathrm{As}, \mathrm{Hg}$ in the global shale layer are 0.29, 16.3, $11.2,0.01 \mathrm{ug} / \mathrm{g} ; I_{g e o}$ is geoaccumulation index, it has no ecological risk when $I_{g e o}$ is lower than 0 , slight ecological risk when $I_{g e o}$ is 0-1, moderate ecological risk when $I_{g e o}$ is 1-2, moderate strong ecological risk when $I_{g e o}$ is 2-3, strong ecological risk when $I_{g e o}$ is 3-4, stronger ecological risk when $I_{g e o}$ is $4-5$, and very strong ecological risk when $I_{g e o}$ is more than 5 (Zhao et al. 2015).

\section{Results of atmospheric ecological risk}

According to the formula 4, the geoaccumulation indexes of the atmospheric heavy metals in coal utilization phase of Xuzhou are as shown in Table 6.

Table 6 Geoaccumulation indexes of atmosphere heavy metals.

\begin{tabular}{cccccc}
\hline Company & Sample & $\mathrm{Cd}$ & $\mathrm{Pb}$ & $\mathrm{As}$ & $\mathrm{Hg}$ \\
\hline Sample & Primary flue gas & 7.86 & -3.06 & 1.51 & 8.45 \\
source 1 & Net flue gas & 11.03 & -2.28 & 1.73 & 8.11 \\
\hline Sample & Primary flue gas & 8.01 & -3.31 & 1.37 & 8.25 \\
source 2 & Net flue gas & 9.30 & -3.53 & 3.37 & 8.33
\end{tabular}




$\begin{array}{cccccc}\text { Sample } & \text { Primary flue gas } & 6.85 & -4.19 & 4.41 & 6.96 \\ \text { source 3 } & \text { Net flue gas } & 8.00 & -3.80 & 4.63 & 6.33\end{array}$

The geoaccumulation indexes of the four kinds of heavy metals in primary flue gas and net flue gas are followed by $\mathrm{Cd}>\mathrm{Hg}>\mathrm{As}>\mathrm{Pb}$. The geoaccumulation indexes of $\mathrm{Cd}$ and $\mathrm{Hg}$ in primary flue gas and net flue gas are all higher than 5, and their ecological risk are very strong; the geoaccumulation indexes of $\mathrm{Pb}$ in primary flue gas and net flue gas are negative, and it does not present the ecological risk characterization; 50\% of the geoaccumulation indexes of As are between 3 and 4, and it has a strong ecological risk.

The geoaccumulation indexes of $\mathrm{Cd}$ and As in primary flue gas are lower than net flue gas, which indicates that the ecological risk of $\mathrm{Cd}$ and As in primary flue gas is lower than that of net flue gas. The geoaccumulation indexes of $\mathrm{Hg}$ in primary flue gas are close to that in net flue gas.

\section{Conclusions and proposals}

The coal exploitation and utilization are a complex periodic process. The paper divided the whole coal life cycle, analyzed each phase characteristics, and took coal in Xuzhou, China, as an example to assess the ecological risk in coal utilization phase. Based on the research results, coal and coal mine characteristics, and the whole life cycle connotation, the whole coal life cycle can be divided into five phases: coal mining, processing, transportation, utilization, and wastedisposal. The priority for production organization and characteristics in the five phases are different. In coal mining phase, the main characteristics are that the key ecological factors (water, soil, atmosphere, vegetation, etc.) are damaged and the primary eco- system is interfered; waste discharged and the water and soil ecosystem damaged are main characteristics in coal processing phase; the characteristics in coal transportation phase mainly performances as the migration and diffusion of atmospheric pollutants, and human ecosystemis disturbed; in coal utilization phase, the main characteristics are that greenhouse effect aggravates, and atmospheric ecosystem is destroyed; the main characteristics is negative ecological effects accumulating on the land in waste disposal phase. The ecological risk of soil heavy metals and atmospheric solid suspended matter is serious in coal utilization phase. A) The potential ecological risk coefficients of $\mathrm{Pb}$ and $\mathrm{As}$ in coal, residue, and ash are all lower than 40, and their environmental impact on soil present low pollution; the potential ecological risk coefficients of $\mathrm{Cd}$ are higher than 60, and nearly half of them are higher than 160, its environmental impact on soil exists high pollution; the Hg's potential ecological risk coefficients are higher than 320, and its environmental impact on soil is very high pollution; the comprehensive pollution indexes in coal, residue, and ash are relatively higher, which have higher potential pollution hazard on soil environment. B) The ecological risk of $\mathrm{Cd}$ and As in primary flue gas are lower than net flue gas. The geoaccumulation indexes of $\mathrm{Cd}$ and $\mathrm{Hg}$ in primary flue gas and net flue gas are higher than 5, and their ecological risk are very strong; $50 \%$ of the geoaccumulation indexes of As are between 3 and 4, and it has a strong ecological risk; $\mathrm{Pb}$ does not present the ecological risk characterization. 
Each phase characteristics of the whole coal life cycle are different, and the environmental behavior and ecological negative effects are also different. It is necessary to take appropriate measures to relieve the ecological pressure in the process of coal exploitation and utilization. Proposal one, constructing reclamation projects in coal mining phase, such as land reclamation, adding soil amendment, and planting restoration vegetation. Proposal two, realizing clean production in coal processing phase by enhancing processing technology, improving the production management system, etc. Proposal three, developing green technology in coal utilization phase, such as desulfurization, denitrification, and advanced dust control technologies.

\section{Acknowledgments}

We gratefully acknowledge the financial support from the National Natural Science Foundation of China (51374208) and National Science and Technology Basic Project (2014FY110800).

\section{References}

Alvaro R, Edson B, Raphael M (2015) A life cycle assessment of the Brazilian coal used for electric power generation. J Clean Prod 92: 179-186

Awuah-Offei K, Adekpedjou A (2011) Application of life cycle assessment in the mining industry. Int J Life Cycle Ass 16: 82-89

Burchart-Korol D, Fugiel A, Czaplicka-Kolarz K, Turek M (2016) Model of environmental life cycle assessment for coal mining operations. Sci Total Environ 562: 61-72

Babbitt CW, Lindner AS (2008) A life cycle comparison of disposal and beneficial use of coal combustion products in Florida. Life Cycle Ass 13: 202-211

Bukowski P (2015) Evaluation of water hazard in hard coal mines in changing conditions of functioning of mining industry in upper Silesian coal basin-USCB (Poland). Arch Min Sci 60: 455-475

Chinh LD, Gheewala SH, Bonnet S (2007) Integrated environmental assessment and pollution prevention in Vietnam: The case of anthracite production. J Clean Prod 15: 1768-1777

Consoil F, Allend D, Bousted I (1993) Guidelines for life-cycle assessment a code of practice. STEAC. Pensacola, FL

Dai GM (2013) Research in the environment influence of railway coal transportation based on fuzzy theory. Dissertation, Dalian Maritime University

Distsele O, Awuah O (2012) Effect of mine characteristics on life cycle impacts of US surface coal mining. Int J Life Cycle Ass 17: 287-294

Dong JH, Bian ZF, Yu M, Die CL (2010) Distribution of heavy metals in reclamation soils of mining area. J China Univ Min Tech 39: 335-341

Donoghue AM (2000) The design of hazard risk assessment matrices for ranking occupational health risks and their application in mining and minerals processing. Soc Occup Med 51: 118-123

Fan QX, Ao HG, Meng C (2007) Life cycle assessment. Environ Sci Manag 32: 177-180

Finnveden G, Hauschild MZ, Ekvall T, Guinee J, Huijungs R, Hellweg S, Koehler A, Pannington D, Suh S (2009) Recent developments in life cycle assessment. J Environ Manag 91: 1-21

Hu Y, Zhou L, Wei C (2013) Study on spatial variability of soil heavy metals environment and its pollution 
characteristics in Beijing water protective area. Chinese J Soil Sci 44: 1483-1490

ISO/DIS (1997) Environmental Management-Life Cycle Assessment-Part Principles and Framework

Lei YJ, Yao J, Zhao F, Li Z (2014) LCA environmental impact assessment of two treatment methods of household garbage in Chengdu city. Safety Environ Eng 21: 75-79

Li YF (2009) Study of the measurement of the effect of coal resource development on resource environment in mining area. J China Univ Min Tech 38: 1-2

Liang XY, Wang ZH, Zhou ZJ (2013) Up-to-data life cycle assessment and comparison study of clean coal power generation technologies in China. J Clean Prod 39: 24-31

Liberda EN, Tsuji LJS, Peltier RE (2015) Mining in subarctic Canada: Airborne PM2.5 metal concentrations in two remote First Nations communities. Chemosphere 139: 452-460

Loska K (2004) Metal contamination of farming soils affected by industry. Environ Int 30: 159-165

Ma FC, Wang JC, Zhang YT (2010) The knowledge map of domestic life cycle theory studies. Intell Sci 28: 334-340

Mangena SJ, Brent AC (2006) Application of a life cycle impact assessment framework to evaluate and compare environmental performances with economic values of supplied coal products. J Clean Prod 14: 1071-1084

Mukherjee AB, Zevenhoven R, Bhattacharya P, Sajwan K, Kikuchi R (2008) Mercury flow via coal and coal utilization by-products: A global perspective. Resour Conserv Recy 52: 571-591

Naser AO, Timothy TC (2008) Life cycle analysis of UK coal fired power plants. Energ Convers Manage 49: $212-220$

Peng CZ (2012) Study on life cycle environmental impact assessment of residential building. Dissertation, Chang'an University

Qian MG, Xu JL, Miao XX (2003) Green technology in coal mining. J China Univ Min Tech 32: 343-348

Solveig GWT (2005) Coal cleaning: A viable strategy for reduced carbon emissions and improved environment in China. Energ Policy 33: 525-542

Steinmann ZJN, Hauck M, Karuppiah R, Laurenzi I, Huijbregts M (2014) A methodology for separating uncertainty and variability in the life cycle greenhouse gas emissions of coal-fueled power generation in the USA. Int J Life Cycle Ass 19: 1146-1155

Tong RP, Zhai YB, Liu XX (2013) A health damage evaluation method of coal mine dust in its life cycle. China Safety Sci J 23: 126-131

Xiang D, Yang SY, Li XX, Qian Y (2015) Life cycle assessment of energy consumption and GHG emissions of olefins production from alternative resources in China. Energ Convers Manag 90: 12-20

Wang BT, Bao YH, Li YH (2012) Discussion on the comprehensive utilization of coal deep processing and waste in China. Shanxi Coal 1: 25-27

Wang C (2011) Research of electrical coal supply chain's waste gas emissions based on coal life cycle. Dissertation, Beijing Jiaotong University

Wang F (2013) A strategic evaluation model and empirical research for mineral resources—a case study on coal resources of China. Dissertation, China University of Geosciences

Wang LP (2007) Grasp the outward expansion multiple of life cycle of coal mine. China Coal Ind 12: 47-48

Wang MX, Bao YH, Wu WL, Liu W (2006) Life cycle environmental impact assessment of winter wheat in north China plain. J Agro-Environ Sci 25: 1127-1132 
Wang XS, Qin Y (2006) Accumulation and identification of heavy metals in Xuzhou urban topsoil. J China Univ Min Tech 35: 84-88

Wang XF, Wang YJ, Li YF (2009) Simulation and prediction for land utilization structural evolution in mine area based on lifecycle theory. Geophys Res 28: 379-390

Wu Y (2014) The research on environmental impact assessment in coal-burning power plants. Dissertation, North China Electric Power University

Zhao Q, Li Q, Xie J, Li Y, Ji Y, Pang C, Wan M (2015) Characteristics of soil heavy metal pollution and its ecological risk assessment in south Jining distract using methods of enrichment factor and index of geoaccumulation. Rock Miner Anal 34: 129-137

Zheng Y (2014) Relationships between a calculated mass concentration and a measured concentration of PM2.5 and reparable particle matter sampling direct-reading instruments in Taconite Mines. J Korean Soc Occup Environ Hyg 24: 65-73

Zhu XF (2004) Study on life cycle methodology. Stud Sci Sci 22: 566-571

Zhuang X, Jiang KJ (2009) Analysis on energy content of coal product from coal mine to user. China Energ 31: $30-36$ 